\title{
VALUE ORIENTATIONS AND ATTITUDES OF THE STUDENTS IN THE REPUBLIC OF MACEDONIA
}

\author{
Antoanela Petkovska, PhD, \\ Institute of Sociology, Faculty of Philosophy - Skopje, Ss. Cyril and Methodius University \\ antoanela@fzf.ukim.edu.mk \\ Mihajlo Popovski, PhD,
}

Institute of Psychology, Faculty of Philosophy - Skopje, Ss. Cyril and Methodius University

mihajlo@fzf.ukim.edu.mk

Konstantin Minoski, PhD,

Institute of Sociology, Faculty of Philosophy - Skopje, Ss. Cyril and Methodius University, konstantin@fzf.ukim.edu.mk

Marija Dimitrovska, MA,

Phd Candidate at Institute of Sociology, Faculty of Philosophy - Skopje, Ss. Cyril and Methodius University marija@sociolozi.org.mk

\section{Abstract}

The aim of this paper is to determine the dominant value orientations of the students and their attitudes towards certain social circumstances, practices and life experiences in terms of the conditions, possibilities and challenges of the socio-cultural ambiance of the contemporary Macedonian society. The survey included 200 participants which are students at "Ss. Cyril and Methodius" University in Skopje and University "St. Kliment Ohridski" in Bitola. The data derived from a Questionnaire developed within the project "Research on European Values of the Citizens of the Republic of Macedonia". The analyses rely on students' responses to questions relating to: the role and significance of certain social institutions; trust in other people, social groups and institutions; the satisfaction of one's own life; desired goals in life; preferences in the use of leisure time; attitudes towards work, family, religiosity and social engagement; assessment of the living conditions in the country and the possibilities for a change; acceptance of different models of behavior and lifestyles; and their preference of certain ideological orientations. The results show that students in general tend to incline towards more traditional value systems. However, we identified some contradictions which indicate the existence of a clash in their value systems.

Keywords: value orientations, attitudes, practices. 


\section{Introduction}

\section{The Social and Cultural Characteristics of Contemporary Macedonian Society}

The culture of living and the value orientations of the youth in the Republic of Macedonia are influenced by the current states and transformations of contemporary Macedonian society. This is a period marked by the processes of gaining independence, establishing independent sovereignty and statehood of Macedonian society outside the former SFRY under the constitutional name of the Republic of Macedonia. ${ }^{1}$ In the case of Macedonia this also entailed reconstruction of the political system, that is, a transition from socialism into capitalism, expressed through establishing political pluralism, democracy and market economy as the fundamental ideological and political values and practices of the newly formed state entity.

The expected consequences of this social transformation were: the development of new institutions in all segments of social life; individual and group mobility intensification (social stratification), and promotion of the values of civil culture and the 'new' culture of capitalism. The evident re-affirmation of the national, cultural and historical identity and structure of Macedonian society were of particular importance. These processes and tendencies also resulted in new policies in terms of self-positioning and self-reflection of the Macedonian social and state milieu, in the context of the recent conditions in the region, as well as in the context of the global positioning of the Republic of Macedonia.

Expectedly, all these features and states effectuate changes in individual and group social practices, lifestyles and life orientations, in terms of their restructuring on the scale of social mobility, the access to centres of power, and the possibility and preparedness for social action.

\section{The Subject of Research}

In recent decades, the worldwide interest in youth, both socially and academically, has been growing continually. There are several important reasons why the discourses related to this particular social group have achieved such significance: the first reason is certainly the interest of contemporary societies into the adequate social integration of youth; the second reason is related to the fact that young people, by adopting social values, are expected to secure the stability of the society, and the third, opposite expectation, is that the rebelliousness, innovativeness and creativity of youth will act as the true corrective of society and instigate social change. The youth are addressed both as a social category that is the fundamental and necessary generator of reproduction, as well as of social development; and, in certain contexts, as the source of problems and the category most affected by the problems in society (Schizerrotto \& Gasperini, 2001). The

\footnotetext{
${ }^{1}$ Between 1945 and 1991, the Republic of Macedonia was part of the Socialist Federal Republic of Yugoslavia. Following the referendum of 8 September 1991, Macedonia declared its independence from the Federation and started a process of transition to a parliamentary democracy and market economy.
} 


\section{Security}

affirmation of the very interest in youth, at a regional level, is evident in the study The Youth in a Time of Crisis (the first research of the Institute of Social Research in Zagreb and the FriedrichEbert-Stiftung in Croatia):

Existing global and local tendencies and processes stimulate social sciences to research a series of phenomena and processes linked to youth which contribute to the understanding of current developments and projections for future development of the society. At the same time, youth population, due to its specific features, is one of the most sensitive seismographs of social change (Ilišin, Boullet, Gvozdanović \& Potočnik, 2013: 9).

In the context of generation, the social status of young people is less favourable because their active participation in social processes is limited by the conventional matrices of role attribution to different age groups. This state of affairs is generated by the controversial integration of youth in the life of the society. One of the consequences of this situation is the appearance of various sub-social and sub-cultural groups with their particular value orientations, modes of behaviour and symbolic meanings. Of course, within their own category, the youth are stratified according to various social parameters (age, gender, social status, local, ethnic and religious affiliation, type and level of education). Thus, it is common to assume that the youth's social and cultural capital is more a result of their passive, rather than active role in society, whereby one should once again take into consideration their inner stratification, as well as the different social circumstances that occasionally create an environment of 'the terror of youth' (which includes insisting on their more serious involvement in the social processes and institutions).

It is important to note that, particularly in more recent sociological research and theories, the idea of the generation has been developed, as a phenomenon that is not unambiguously related to one's birth year or the cohorts of age. According to Todor Kuljić (2009), what marks a generation is in fact its ideological unity, that is to say, the notion of class is substituted by generation in the context of the determining factors important to stimulating social development. They constitute a unity because of their unification around certain worldviews and life perspectives. Thus, generations may in fact be defined only from a perspective of an a posteriori comparison of present with future generations. The given social context with its political, historical, cultural, and economic characteristics, in fact, nevertheless creates a common environment for the population of a similar age, which supports the idea of difference only in the context of their social positioning in terms of status.

Mannheim systematically deals with the issue of the generations as 'socially located' individuals, and not classically sociologically defined social groups:

The fact of belonging to the same class, and that of belonging to the same generation or age group, have this in common, that both endow the individuals sharing in them with a common location in the social and historical process, and thereby limit them to a specific range of potential, experience, predisposing them for a certain characteristic mode of thought and experience, and a characteristic type of historically relevant action (Mannheim, 1952:291).

The research on youth trends in the Republic of Macedonia (2004), conducted over a decade ago, claimed that: 


\section{Security}

It is more than obvious that children and the youth in the Republic of Macedonia are the most vulnerable population, as in other so-called 'transitional societies' (even though society in principle is constantly developing and changing, but in this case, transitional systems are a euphemism for radical, revolutionary changes, or for a transition from one into another system, regardless of the quality of the change). The conflict of the different value system that Macedonia faces (identified in the youth in other European countries as well, as demonstrated by the results of certain recent research projects, for instance European Youth Trends): the traditional system of values, the socialist (or humanist) system of values and the contemporary (postmodern or postmodern), produces a lack of criteria or orientations in building a consistent social and cultural identity of the youth (Youth and Sports Agency, 2004).

The characteristics of societies facing radical social changes, which appeared to be the reasons for social trauma (Giddens and Sztompka) and cultural trauma (Alexander and Sztompka), were noted in the abovementioned Croatian study on the youth:

Risks which additionally make social integration of youth more difficult are even more numerous and more prominent in transitional societies - compared with the earlier socialist times, and compared to more developed and stable democratic societies. Namely, growing up in postsocialist societies is burdened with a double transition, because young people are passing through a universal transition period from childhood to adulthood in societies which are at the same time undergoing a fundamental transformation. Socialization of young people takes place in unstable conditions, because institutions, processes and social norms which in the past guided the transition into adulthood are also undergoing a more or less radical change. Analyses have so far indicated that young people in transition countries are facing a series of processes which make adequate integration into adult world more difficult (Ilišin, Bouillet, Gvozdanović, \& Potočnik, 2013:10-11).

The subject of this paper are the value orientations and attitudes of part of the student population in the Republic of Macedonia placed in the context of certain social conditions. It incorporates data analyses related to several aspects of the lives, practices and values of the participants in the research, such as: the role and the significance of certain social institutions and social practices; the trust in people, social institutions and certain social groups or groups with certain lifestyles; the desired life goals; priorities in organising their free time; their attitudes towards work, family and religion; social engagement; evaluation of the living conditions in the Republic of Macedonia, as well as the possible ways to change/improve them; the preferences for certain lifestyles, and the preferences for certain ideological orientations.

The analyses aim to get sociologically postulated findings on possible dominant and differentiated value orientations and lifestyles of the student population in the Republic of Macedonia, seen through the socio-cultural context of contemporary Macedonian society. In this discourse value orientations are seen as a structure, a more or less open system, which includes a collection of views, desired goals, common modes of behaviour and established lifestyles of a certain population, framed in the context of an objective social reality.

This research covers a specific period in the contemporary social processes of the Macedonian (post)transitional society, which is expected to be related to: the clear effects of social and 


\section{Security}

cultural trauma (mistrust of people and institutions, political apathy, a sense of alienation from the public sphere and retreating into the individual sphere, the illusion of defining the habitus); the assumption of a defined relationship to the values of European civilization (democracy, the rule of law, tolerance/political correctness, freedom of speech, gender, ethnic and religious sensitivity, etc.), or the hybridisation of value systems (conservative with liberal).

Considering the defined subject and goals of this paper, the basic assumption in the analyses is that the generation exposed to the effects of social and cultural trauma develops hybrid value systems, evident in the ambivalent relationship to the values of the European civilization. The constellation of local/national, and simultaneously regional/European and global processes produces contradictory value systems in the youth, who are put in the position of unfair choice between the desired and the achievable values.

\section{Methodological Approach}

The analyses in the paper are based on data gathered through a questionnaire, as part of the project Research on European Values of the Citizens of the Republic of Macedonia, realised with financial support from the Ministry of Education and Science of the Republic of Macedonia and the Faculty of Philosophy in Skopje. 22 of a total of 81 questions of the questionnaire were analysed for the purposes of this paper. The general topics of the questions may be defined as follows: preferred life goals of the participants in the research; social distance and trust in other people; cultural and social practice; social activism; attitudes towards marriage and family; religiosity; work ethics, and political and ideological preferences. The research sample was purposive and included 200 students from two public higher educational institutions in the Republic of Macedonia, the Ss. Cyril and Methodius University in Skopje (the Faculty of Philosophy and the Faculty of Law), and the St. Kliment Ohridski University in Bitola (the Faculty of Law in Bitola, Kičevo and Struga). The research participants were aged 18 to 22 and higher, 33\% of which were male and 67\% female. The survey was realized in the period between 0ctober and December 2013.

\section{Analyses}

The participants' orientation towards certain aspects of life was realised with a question which contained several alternatives determining the importance of those things in their lives, such as: work, family, friends and acquaintances, leisure, politics, religion, education, sports and art. The median values of the participants' answers indicate their focus and their encapsulation in the private sphere and the sphere of personal promotion, as opposed to the aspects of the public sphere in several of its manifestations. In that sense, it is important to note that politics was the least important to them. The ranking of the participants' preferences ${ }^{2}$ shows that they demonstrate strong affiliation to the family $(M=3.96)$, then to education $(M=3.89)$, work $(M=3.68)$, friends and acquaintances $(M=3.64)$, leisure $(M=3.40)$, sports $(M=2.82)$, religion $(M=2.68)$, art $(M=2.57)$ and politics ( $M=2.01)$. The students' self-assessment of their general life satisfaction shows moderate satisfaction lives ( $M=3.61$, on a scale of 1 to 5$)$.

2 On a scale of 1 to 4 , where 1 is 'It is utterly unimportant,' and 4 'It is very important.' 


\section{Seccurity}

The preferred life goals allow for the dominant value orientations to be defined. ${ }^{3}$ Namely, the participants' relation to the private sphere was confirmed. The highest ranked is the familial/sentimental orientation ( $M=4.24)$, utilitarianism/orientation to material values $(M=3.90)$, the egotistic orientation $(M=3.70)$, whereas the least desired are the orientation to religion and tradition $(M=2.85)$, orientation to power $(M=2.82)$ and the desire of popularity $(M=2.04)$. A third of the participants do not engage in volunteering and involvement in civil society associations (which would indicate an interest into certain forms of civic activism). On the other hand, with regards to the type of activism, the most prominent kinds of engagement were those related to education, culture, art, sports, and, as expected, youth organisations. The participants are the least involved in organisations with altruistic profiles.

The participants' average interest in civic engagement may, among other things, result from their high level of mistrust $(89.2 \%)$, as well as scepticism regarding other people's intentions. Most participants believe that the majority of people would try to take advantage of them $(M=4.5)^{4}$ This question is related to the answers of assessing other people's egotism-the median value of the responses is $M=3.42 .{ }^{5}$ In contrast to this scepticism, the surprising fact is that the participants believe that they have a high level of control over their lives $(M=7.77){ }^{6}$ which may indicate a certain degree of alienation from other people.

The participants' acceptance of a socially and individually responsible relationship to the work process was identified through their preferred views related to certain aspects work and work ethics. Thus, the greatest acceptance ${ }^{7}$ is shown towards the stance that In order to develop your talent, you need to work hard' $(M=4.74)$, whereas the least, although not a negative identification, is manifested towards the statement that 'Work must always come first, even at the expense of free time' $(M=3.04)$. These orientations indicate the possibility that the young participants have accepted some of the neoliberal values, assumed in the process of social transition from socialism to capitalism. On the other hand, this type of work ethics may be reminiscent of the value system characteristic of their parents' generation, from the socialist period itself.

According to the students' views related to certain aspects of work, one might conclude that most of them recognise the features of the work process that contribute to personal satisfaction, development and indicate a strong sense of sociability within the workplace. The percentage of participants who also grasp the responsibility to society through participating in the process of its reproduction in all spheres of social life is not insignificant. For example, only $30 \%$ of the participants show that they consider the hedonist ambience at the workplace important as well ('lavish holiday celebrations').

Digital communication and communication within the private sphere (socialising with friends and relatives) proved to be most preferable practices for the participants within leisure.

\footnotetext{
${ }^{3}$ The preference of certain value orientations was measured on a scale of 1 to 5 , where 1 stood for 'I would not want at all,' and 5 'I would want the most.'

${ }^{4} \mathrm{On}$ a scale of 1 to 10 , where 1 equals 'Most people will try to take advantage of me,' and 10 'Most people will try to be fair.'

${ }^{5} \mathrm{On}$ a scale of 1 to 10 , where 1 stands for 'Most people care about themselves,' and 10 'Most people help each other.'

${ }^{6} \mathrm{On}$ a scale of 1 to 10 , where 1 expresses the lowest level of control, and 10 the highest.

${ }^{7} \mathrm{On}$ a scale of 1 ('I completely disagree') to 5 ('I completely agree').
} 


\section{Security}

Thus, rather expectedly for the epoch they are part of, the young research participants use their leisure time to browse the Internet on a daily basis $(M=4.88$, on a scale of 1 to 5 , where 1 denotes 'Never,' and 5 'Every day'), followed by the media $(M=4.74)$, socialising through online social networks $(M=4.54)$, and socialising with friends and relatives $(M=4.53)$. At least once a week, the youth frequent cafés and other catering facilities $(M=3.61)$. Less frequently they read books $(M=3.57)$, and engage themselves in sports and recreation $(M=3.55)$. At least once a month, the participants engage in: attending entertainment events $(M=2.96)$, further education and skill acquisition $(M=2.88)$, amateur artistic activities or pursuing hobbies $(M=2.87)$, attending religious institutions $(M=2.58)$, and attending cultural events and institutions $(M=2.56)$. The participants most sparsely engage in attending sporting events $(M=2.27)$ and playing games of chance $(M=2.23)$, practiced at least once a year.

Religiosity and spirituality have an important place in the research, and it also appeared to be relevant to the student population as the basic target group. It is important to bear in mind that the Republic of Macedonia as a former socialist country was mainly oriented to atheism, and as a society in transition to the idea of religious freedom. At the same time, it is necessary to point out the strong connection between the ethnical and the religious identity (e.g. Macedonian with the Orthodox, Albanian with the Muslim, etc.). The analysis of the responses showed that $88 \%$ of the participants declared themselves as members of a religion (92\% of which as Christian, and $5.1 \%$ as Muslim). With regards to the degree of religiosity, the participants mainly declared themselves as moderately religious $(M=3.52)$. The median value of the participants' responses on 'the interest in the spiritual, the sacred and the supernatural,' is $M=2.77$, on a scale of 1 , denoting 'I am not interested at all,' to 4, 'I am very interested.' Some fundamental concepts of the monotheistic religions (particularly Christianity, Islam and Judaism), such as God, sin, the afterlife, heaven and hell, were subject to selection as aspects of religiosity. It turned out that $90.6 \%$ of participants believe in God, there is a drastically lower percentage of those who declared they believed in $\sin (67.9 \%)$, and even lower percentages of participants believe in the afterlife (47\%), in heaven $(42.3 \%)$, and hell $(32.3 \%)^{8}$

\footnotetext{
${ }^{8}$ The relationship towards religious rituals and religious establishments is another important component in determining the type and the degree of religiosity of the participants, particularly because of their significance for monotheistic religions. Consequently, these issues were included in three questions of the questionnaire. The participants declared that they seldom attend religious services, except on special occasions (baptisms, weddings and funerals), even though over two-thirds of them agree that there should always be religious services performed for births, getting married and deaths. The third question is related to the roles of the religious institutions in Macedonia. The participants were offered multiple choices. A majority of them responded that those institutions provide answers to people's spiritual needs (75.6\%), whereas over half of the participants believe that religious institutions do not offer help in solving the individual's moral problems and needs, as well as for the issues related to family life and the social problems one encounters in society. Another question related to practicing religion independently of religious establishments and services is the one concerning the time devoted to prayer. To this question, $46.9 \%$ of students replied that they seldom pray, $33.1 \%$ declared that they pray every day, whereas $19.9 \%$ declared that they pray several times a month.
} 
With regards to the aspects of religious distance and religious tolerance, the participants mainly showed a tolerant attitude, that is, they were not exclusive in terms of the significance of their own religious affiliation and the religious affiliations of others.

The principle of 'spirituality,' that is, the type of religious consciousness of the participants, may be derived through their responses on: the importance of God in their lives (as the central concept of Judaism, Christianity and Islam); the acceptance of the concept of reincarnation (present in other religions and theosophies), and the belief in lucky charms that are theoretically and conceptually related to superstition or magical thinking (characteristic of pagan religions). Considering the religious affiliation of the research participants, it was to be expected that a large number of them would declare that God was important in their lives. However, as many as $36 \%$ of them also believe in reincarnation, and $35.6 \%$ in lucky charms.

The participants' answers to the questions related to marriage and family revealed the contradictions of individual value systems (traditional versus modern). The nature of the questions is concerned with several aspects related to participants' acceptance of formal partner relationships, as well as the factors contributing to the success of such relationships, as well as the gender and generational communication within the family. Consequently, as high as $81.5 \%$ of students believe that marriage is not an out-of-date institution, which may indicate their orientation to traditional forms of social grouping. On the other hand, in assessing the factors for a successful marriage, priority was given to those factors that are part of the private relationship between the spouses (talking about problems, fidelity, and agreement on child rearing, happy sexual relationship, whether to have children and to have time for friends and acquaintances). They perceive the factors related to existence and traditional relationships (good living conditions, a decent income, sharing household chores, living separately from the parents, sharing the religious and ethnic affiliation) as somewhat less important ${ }^{9}$, and the least important were the factors related to the broader social context, that is, the factors concerning the belonging to the same class, ideological and political preferences.

\section{Table 1. Factors of successful marriage}

\begin{tabular}{|l|c|c|c|}
\hline Factors of successful marriage & N & M & Ranking \\
\hline Faithfulness & 199 & 3.74 & 2 \\
\hline An adequate income & 199 & 3.14 & 8 \\
\hline Being of the same social background & 200 & 2.10 & 13 \\
\hline Shared religious beliefs & 195 & 2,80 & 11 \\
\hline Same ethnic background & 197 & 2.65 & 12 \\
\hline Good housing & 198 & 3.38 & 7 \\
\hline
\end{tabular}

\footnotetext{
${ }^{9}$ It should be noted that the importance of living separately from the parents and the financial independence are significant in terms of the long tradition and the frequency of cases of extended families in the period of socialism, but particularly in the period of transition, when many young married couples were forced to live together (with parents, brothers and sisters and their families) on account of their financial dependence on their parents.
} 


\begin{tabular}{|l|c|c|c|}
\hline Agreement on politics & 197 & 1.58 & 14 \\
\hline Living apart from your in-laws & 199 & 2.90 & 10 \\
\hline Happy sexual relationship & 199 & 3.60 & 4 \\
\hline Sharing household chores & 199 & 2.96 & 9 \\
\hline Children & 198 & 3.55 & 5 \\
\hline To agree on the child rearing approach & 197 & 3.66 & 3 \\
\hline $\begin{array}{l}\text { Being willing to discuss the problems that come up } \\
\text { between husband and wife }\end{array}$ & 198 & 3.81 & 1 \\
\hline $\begin{array}{l}\text { Having some time for one's own friends and for } \\
\text { personal hobbies/activities }\end{array}$ & 199 & 3.43 & 6 \\
\hline
\end{tabular}

The general attitude towards the type of family relationships were mainly identified through the relations between the spouses (gender relations). The participants demonstrated highest level of agreement towards the attitude that spouses should independently decide on having a progeny, to equally share the responsibility for the children and to contribute equally to the family income. There is partial agreement with the attitudes that the father could take just as good care of the children as the mothers, that working mothers are just as good as the stay-athome mothers, that it is acceptable for a couple to live together without getting married, that for a woman's independence it is important to have a job, that a long-term relationship is necessary for achieving happiness and that the man feels fulfilled when he has children. In terms of the attitude that the woman prioritises the home and the children over work and that housewives are just as fulfilled as working women the participants are rather undecided. Finally, the lowest acceptance is demonstrated towards the position that having children is an obligation to society that the children would suffer if their mother worked and that homosexuals should be allowed to adopt children.

Table 2. Claims about marriage

\begin{tabular}{|l|r|r|l|}
\hline \multicolumn{1}{|c|}{ Claims about marriage } & N & M & Ranking \\
\hline $\begin{array}{l}\text { A man has to have children in order to } \\
\text { be fulfilled }\end{array}$ & 194 & 3.53 & 9 \\
\hline $\begin{array}{l}\text { A marriage or a long-term stable } \\
\text { relationship is necessary to be happy }\end{array}$ & 199 & 3.55 & 8 \\
\hline $\begin{array}{l}\text { Homosexual couples should be able to } \\
\text { adopt children }\end{array}$ & 197 & 1.95 & 14 \\
\hline $\begin{array}{l}\text { It is alright for two people to live } \\
\text { together without getting married }\end{array}$ & 200 & 3.80 & 6 \\
\hline
\end{tabular}




\begin{tabular}{|l|l|l|l|}
\hline $\begin{array}{l}\text { It is a duty towards society to have } \\
\text { children }\end{array}$ & 197 & 2.26 & 12 \\
\hline $\begin{array}{l}\text { People should decide for themselves } \\
\text { whether to have children or not }\end{array}$ & 200 & 4.75 & 1 \\
\hline $\begin{array}{l}\text { A working mother can establish just as warm and } \\
\text { secure a relationship with her children as a mother } \\
\text { who does not work }\end{array}$ & 199 & 4.13 & 5 \\
\hline $\begin{array}{l}\text { A pre-school child is likely to suffer if his or her } \\
\text { mother works }\end{array}$ & 199 & 2.19 & 13 \\
\hline $\begin{array}{l}\text { A job is alright but what most women really want } \\
\text { is a home and children }\end{array}$ & 198 & 3.43 & 10 \\
\hline $\begin{array}{l}\text { Being a housewife is just as fulfilling as working } \\
\text { for pay }\end{array}$ & 194 & 2.76 & 11 \\
\hline $\begin{array}{l}\text { Having a job is the best way for a woman to be an } \\
\text { independent person }\end{array}$ & 197 & 3.73 & 7 \\
\hline $\begin{array}{l}\text { Both the husband and wife should contribute to } \\
\text { household income }\end{array}$ & 199 & 4.62 & 3 \\
\hline $\begin{array}{l}\text { In general, fathers are as well suited to look after } \\
\text { their children as mothers }\end{array}$ & 200 & 4.31 & 4 \\
\hline $\begin{array}{l}\text { Men should take as much responsibility as women } \\
\text { for the home and children }\end{array}$ & 4.72 & 2 \\
\hline
\end{tabular}

Several questions addressing certain liberal or liberal or traditionalist orientations were identified through the participants' attitudes towards gender equality. For example, the respondents were asked whether a woman should have children or if she could feel fulfilled without having children. The majority of research participants $(71.3 \%)$ agreed with the stance that women should have offspring in order to feel fulfilled. Furthermore, $66.5 \%$ of participants approve of the statement that it is acceptable for women to be single mothers.

The respondents were given the opportunity to express their opinion on abortion under different circumstanced. There was an overwhelming tendency to justify abortion in cases when the woman was raped (90.5\%). Furthermore, abortion is justified when the pregnancy is endangering the life of the mother (89.8\%), and if the woman is carrying a foetus with abnormalities (86\%). Moreover, $76 \%$ of participants justify abortion when the woman got pregnant against her will. Abortion is much less justified when the married couple does not want any more children ( $56.2 \%$ disapprove) and when the woman is not married ( $58.3 \%$ disapprove). It could assumed that the participants show tendencies of empathy and humaneness related to the woman's physical and psychological health when approving the act of abortion. 


\section{Security}

The respondents once again had the opportunity to express their views on the values they would like to transmit to their offspring. This issue is of a particular significance considering that it almost explicitly indicates the criteria important to the hierarchisation of the value system of the respondents. Four values were identified as the most important in child rearing: honesty $(81 \%)$, sense of responsibility $(78.2 \%)$, tolerance and respect $(75.4 \%)$ and good manners $(75.3 \%)$. The second group of values important for child rearing includes: ambition (58.3\%), hard work $(57.5 \%)$, independence $(54.4 \%)$, and resoluteness and perseverance (57.2\%). In the third group, the percentage of expressed importance is lower than $50 \%$, such as in: obedience $(41.9 \%)$, selflessness $(40.8 \%)$, or cooperativeness (34.2\%). The least important values for child rearing involved: religiosity $(29.7 \%)$, frugality $(28.9 \%)$, imaginativeness $(23.8 \%)$ and curiosity $(23.4 \%)$.

The views on the nature of the parent-child relationship may particularly be seen through the responses on the questions whether parents should be respected unconditionally (with which $64 \%$ of research participants agreed) and the question whether parents should sacrifice for their children (80.5\% agree with this claim).

The level of acceptance of certain modes of behaviour of individuals and groups was measured through 18 items, on a scale of 1 to 10 , where 1 marks the lowest level of acceptance or 'absolutely unacceptable,' whereas 10 denotes a complete acceptance of the behaviour as justified. Once again, the aspects of the private/emotional sphere were considered as the most acceptable: in vitro fertilisation $(M=7.93)$, divorce $(M=6.59)$ and casual sex $(M=6.34)$. In relation to abortion $(M=5.35)$, cash payments to avoid taxation $(M=5.32)$ and euthanasia $(M=4.54)$, the participants show a relatively personal attitude to the types of behaviour that have a broader social dimension. A lower level of approval was expressed in relation to capital punishment $(M=3.81)$, homosexuality $(M=3.69)$, using soft drugs $(M=3.61)$, not paying for a ticket on public transportation $(M=3.57)$ and lying $(M=3.38)$. The types of behaviour such as adultery $(M=2.85)$, prostitution $(M=2.68)$, taking money from the state without having the right to $(M=2.67)$, suicide $(M=2.67)$, human embryo experimentation $(M=2.38)$, and the genetic manipulation of food $(M=2.37)$ were identified as highly unacceptable, whereas taking bribes $(M=1.84)$ and tax evasion $(M=1.76)$ were deemed as least acceptable.

Social distance of the respondents was measured through a question in which research participants could declare which social groups or individuals with particular lifestyles or behaviours they would accept as neighbours. The analyses of the responses demonstrated that the participants showed the greatest social distance towards people with deviant behaviour (drug addicts, severe alcoholics, criminals) or towards people that may threaten their physical integrity, their health, or disturb their families' peace and security (mentally ill individuals, people with AIDS, and the like). Apart from the social distance manifested towards Albanians and Romani, the degree of ethnic and religious distance is not high. The low level of distance is also expressed regarding people with a different economic and social status (extremely poor people, people with large families, villagers), and with a different ideological/political orientation. The participants' responses are presented in Table 3. 
Table 3. Social distance from certain individuals and groups

\begin{tabular}{|l|l|l|}
\hline & I would mind (\%) & I would not mind (\%) \\
\hline People with a criminal record & 79.9 & 20.1 \\
\hline Heavy drinkers & 81.7 & 18.3 \\
\hline People with large families & 7.7 & 92.3 \\
\hline Turks & 7.7 & 92.3 \\
\hline Vlachs & 6.8 & 93.2 \\
\hline Macedonians & 2.0 & 98.0 \\
\hline Romani & 29.0 & 71.0 \\
\hline Serbs & 7.6 & 92.4 \\
\hline Albanians & 32.3 & 67.7 \\
\hline $\begin{array}{l}\text { People who have just moved from the } \\
\text { country }\end{array}$ & 8.2 & 91.8 \\
\hline People with a physical disability & 8.6 & \\
\hline Emotionally unstable people & 52.8 & 91.4 \\
\hline People with AlDS & 48.7 & 47.2 \\
\hline Drug addicts & 82.9 & 51.3 \\
\hline Homosexuals & 49.9 & 17.1 \\
\hline Immigrants & 6.0 & 53.1 \\
\hline Jews & 11.8 & 94.0 \\
\hline Muslims & 18.6 & 88.2 \\
\hline Christians & 3.6 & 81.4 \\
\hline Religious fanatics & 49.2 & 96.4 \\
\hline People of a different ethnicity & 9.0 & 50.8 \\
\hline $\begin{array}{l}\text { Individuals with different political } \\
\text { orientation }\end{array}$ & 7.7 & 91.0 \\
\hline Extremely poor people & 7.7 & 92.3 \\
\hline
\end{tabular}

One part of the questionnaire was aimed at determining the political and ideological preferences of the respondents. The forms of political activity or civic activism for which the participants had the opportunity to take a position indicate a tendency of a relatively high level of preparedness to participate in legitimate and, above all, legal form of expressing civil dissatisfaction. The results are presented in Table 4. 
Table 4. Approving forms of political activity

\begin{tabular}{|l|c|c|c|}
\hline & $\begin{array}{c}\text { I have participated } \\
\text { (\%) }\end{array}$ & $\begin{array}{c}\text { I may participate } \\
\text { (\%) }\end{array}$ & $\begin{array}{c}\text { I would never } \\
\text { participate (\%) }\end{array}$ \\
\hline Signing a petition & $42.9 \%$ & $42.9 \%$ & $14.3 \%$ \\
\hline Joining in boycotts & $25.1 \%$ & $41.2 \%$ & $33.7 \%$ \\
\hline $\begin{array}{l}\text { Attending lawful } \\
\text { demonstrations }\end{array}$ & $37.2 \%$ & $45.4 \%$ & $17.3 \%$ \\
\hline $\begin{array}{l}\text { Joining unofficial } \\
\text { strikes }\end{array}$ & $15.1 \%$ & $32.3 \%$ & $52.7 \%$ \\
\hline $\begin{array}{l}\text { Occupying buildings or } \\
\text { factories }\end{array}$ & $10.3 \%$ & $30.4 \%$ & $59.2 \%$ \\
\hline
\end{tabular}

Furthermore, the ideological inclination of the respondents was examined through their responses related to the prioritization of the values of freedom and equality. Freedom as a value is important to $73.1 \%$ of participants, and equality only to $26.9 \%$ of participants. Their assessment of the state of affairs in the society and the potential ways to change it, showed that only $0.6 \%$ of participants believe that no change is necessary; that changes should be radical is confirmed by $23.5 \%$ of participants, and as many as $76 \%$ believe that society should be changed gradually, through reforms. The participants identified peace and stability (37.7\%) as priority goals for the country and accelerated economic development $(24.5 \%)$ as second most important. The highest percentage of participants responded that our society is dominated by injustice $(24.4 \%)$ and poverty $(23.3 \%)$. The percentage of participants believing that the citizens of our country are lazy and idle $(23 \%)$ is not much different.

Concerning the acceptance of democratic mode of government, there is an obvious tendency among the participants to place a high value on it $(M=4.08) .{ }^{10}$ This is also evident in the responses to the question that democracy may create problems, but it is better than any other form of governance $(M=4.08) .{ }^{11}$ However, the assessment of the level of satisfaction with democracy in our country indicates low to moderate satisfaction $(M=2.58) .12$

This result is confirmed in the question related to the level of trust expressed towards several national and international institutions. The overall level of trust is $M=2.67$, on a scale of 1 to 5 , where 1 denotes 'No trust,' and 5 denotes 'Complete trust.' The highest level of trust was shown in relation to the educational system $(M=3.25)$ and the army $(M=3.13)$, which indicates moderate trust. The lowest level of trust in national institutions is shown in relation to the media

\footnotetext{
${ }^{10}$ On a scale of 1 to 5 , where 1 stands for 'Very bad' and 5 for 'Very good.'

${ }^{11} \mathrm{On}$ a scale of 1 to 5 , where 1 stands for 'I completely agree,' and 5 for 'I completely disagree.'

${ }^{12} \mathrm{On}$ a scale of 1 to 5 , where 1 stands for 'I am not satisfied at all,' and 5 for 'I am completely satisfied.'
} 
$(M=2.38)$, the trade unions $(M=2.19)$ and the political parties $(M=2.01)$. Of the international organisations, the highest level of trust is shown towards the UN ( $M=2.81)$, and the lowest toward NATO (M=2.63), although the trust in the EU yields a similar result ( $M=2.65)$.

These two blocs of questions confirm the assumption of the discrepancy that appears in the youth's views caused by the irreconcilability between their legitimate expectations (consistent with the ideology of liberalism as a globally accepted ideology) and the real social conditions emanating a series of inconsistencies and traumatic experiences, particularly in the local context (the Republic of Macedonia).

\section{Conclusion}

The processes of transformation of the social and state system in the Republic of Macedonia (establishment of new institutions, acceleration of the social hierarchy, adaptation to new value models, etc.) had repercussions on the identity building (national, cultural, class, gender) of its citizens. In this sense, one should not ignore the processes of establishing the relations of the Republic of Macedonia with the region and the world, and taking a certain position in the new constellation of international relationships. The tumultuous transitional period initiated a national identity crisis, weakening of the social cohesion, increased mistrust in people and institutions, and created a milieu that produced conditions for the youth to be reduced to passive observers rather than active stakeholders in social reality. The sociological analysis showed that there is a generational framework for sharing certain value orientations both in the older and the younger population (Petkovska, Minoski, Popovski, \& Jovanoski, 2012). This situation is consistent from the viewpoint of the sociology of generations (Kuljić, 2009): namely, that akin socio-cultural circumstances generate similar models of value systems.

Generally speaking, from the insight into most of the students' views, one might note their obvious orientation to the private sphere, as opposed to the public one, from which they seem increasingly distant. Basically, this refers to a specific type of conservatism that stems from the economic, political and cultural past of the country. This type of conservatism indicates a need for collective security, characteristic of conservative and traditionalist tendencies. However, this security is pursued in the sphere of intimacy and individual interest or responsibility.

The frustration with life conditions is evidently affecting the moderate degree of life satisfaction identified by the participants. Even the fact that the young respondents expressed to have a high level of control over their lives is indicating aspects of alienation ('I rely on myself, not on other people'). This can be also associated to the students' high level of mistrust and scepticism related to other people. The system's institutions are not recognised as places where it is possible to realise personal initiative, ambition, self-identification and self-valorisation. Vertical mobility, which turned out to be important to students, is being questioned, regardless of the individual's personal affinities. Thus, the institutions of the system discourage a legitimate competitive atmosphere and generate citizens' mistrust. Mobility is conditioned by the innovative strategy in a Mertonian sense of the word (Merton, 1968), but the participants are reserved in relation to the legitimately provided means to achieve it (hard work, education as value, work as a calling, 


\section{Seccurity}

sacrificing free time). Consequently, the elements of the familial/sentimental orientation, as those of the utilitarian and the egotistical orientation are the most present in the participants' choices of value systems. The values of honesty, responsibility, tolerance and respect, as well as good manners are things that young people would most gladly transmit to their progeny. Thereby they decide on a way of life that is morally suitable, but also intimately acceptable in the primary groups.

The view on marriage, family and family values, partner relationships, parent-child relationships once again indicate the duality of value systems of the students, which involves a mild orientation to liberal/individual values and preferences, but also an undoubtable latent connection to traditional pro-conservative tendencies, inherent to our culture (Петковска, Поповски, \& Јованоски, 2010).

The youth's position on certain aspects of work and work ethics implies an acceptance of neoliberal tendencies assumed in the process of social transition from socialism to capitalism. For instance, they recognise the features of the work process contributing to the personal satisfaction and development and indicate a strong sense of the sociability expected in the workplace. A certain percentage of research participants also show that they have grasped their responsibility to society through responsible participation in the process of social reproduction in all spheres of social life.

The preference for certain practices in the leisure time constitutes another evidence that the students have accepted the contemporary modes of communication (digital communication) and orientation to the Internet, which is a practice shared by their peers at a global level. The traditional attitude towards life outside the work process is manifested in their orientation towards their family and friends.

The high level of declared religiosity and the fact that two-thirds of the young participants find comfort in religion may lead us to contradictory conclusions. One of the reasons for this derives from the recent global tendencies in which one recognises a return to the conservative values of tradition, whose greatest exponent is the revitalisation of religion. On the other hand, the degree of alienation and the constant search for a national and cultural identity is something in which even the young, who are assumed to be more open to the world, find their existential outcome.

Consequently, young respondents manifest higher tolerance of the religious affiliation of the other, but lowest tolerance of atheists/unbelievers. The manner in which the young respondents relate to religious phenomena demonstrates an evident inclination towards traditional type of religiosity (basic rituality, insufficient familiarity with religious concepts, practicing religion within the private sphere-an individualised relationship to the otherworldly, as opposed to the public participation in religious rituals) rather than a syndrome of convinced believers.

The greatest social distance is manifested towards people with deviant behaviours (drug addicts, severe alcoholics, criminals), or towards people who are perceived as a potential threat to someone's physical integrity, the health, peace and safety of their immediate surroundings (mentally ill individuals, people with AIDS, etc.). As mentioned, the degree of religious distance is not high, and the same goes for ethnic distance, except in relation to the Albanians and the Romani 


\section{Security}

(which could be related to the ethnic tensions in Macedonian society). People with low economic and social status, or with different ideological/political orientation have not been perceived by the respondents as hostile. This kind of manifested empathy towards marginalised groups and the expressed resistance to ideological division that has a negative impact on the cohesive fabric of society is characteristic of contemporary Macedonian society per se.

The acceptance and the assessment of the everyday behaviour of people in once again showed that the young respondents value the aspects of the private/emotional sphere (for example, in vitro fertilisation, divorce and casual sex). The attitudes towards certain practices, such as abortion, cash payments to avoid taxation, as well as euthanasia, indicate a relatively personal relationship to the type of behaviour that has more serious social implications. A similar relationship is demonstrated with regards to some other types of social behaviour (mainly deemed as socially unacceptable), such as: capital punishment, homosexuality, using soft drugs, not paying for a ticket on public transport and lying. The behaviours which are a subject of a traditionally moralising attitude, or those for which, generally, the public shows less understanding, have also been found unacceptable by the young respondents. The participants' views on these issues should certainly be placed in relation to the age of the target group and to the current social ambience. Nevertheless, the identified duality in the attitudes towards certain types of behaviour, expressed in the young respondents' preferences does not correspond to the expected notion that they are largely open to different forms of social life, more than the older generations, who are expected to show attitudes learned during different social circumstances (pragmatism, 'strictness,' political correctness, but also exclusiveness).

If the openness to certain forms of civic activism is an indicator of the potential for agency in this generation, the participants showed a certain readiness to participate in some legal forms of protest. However, their views on the need for a gradual change of society, their mistrust in the system's institutions, as well as in the international institutions, the unpreparedness for unconventional forms of activism may be interpreted as a tendency to distance themselves from the possible repercussions that might results from such proactivity. Freedom and democracy matter to them, but they would practice them through reforms rather than through radical changes.

Fundamentally, the young respondents recognise democracy as a relatively desired model of governing society. However, the manner in which its principles are implemented in the Republic of Macedonia is judged with a mild dose of criticism. Their attitudes towards democracy compared to the level of trust in various institutions, do not indicate a particular determination and consistency in their ideological/political views.

The results of the research confirm the assumption that young people show a tendency for hybrid value system (between traditional and contemporary values), with recognizable elements of both a libertarian and authoritarian ideological point of view. This situation may not be exclusively related to the Republic of Macedonia, and bearing in mind all the processes that emanate a crisis of the system, indicate the existence of a bipolarity in the young people's value orientations that might have a long-term negative effect on their further socialisation. On the other hand, the relatively moderate trust in international institutions (low to moderate) indicates scepticism in 
relation to the role of the international community in designing the political system in Macedonia. The value preferences of the young respondents indicate a discrepancy inherent in their views as a result of their inability to reconcile their legitimate expectations (consistent with the ideological premises of liberalism as a globally accepted ideology) and the real social conditions in the internal and external relations of the Republic of Macedonia, which are manifested through a series of paradoxical and traumatic experiences.

The assumption regarding the effects of social and cultural trauma (mistrust in people and institutions, political apathy, alienation) has been confirmed. Moreover, there is evidence of a not clearly defined position towards the values of European civilization (democracy, the rule of law, tolerance/political correctness, freedom of speech, gender, ethnic and religious sensitivity, etc.). Thus, these young representatives of the so-called transitional generations exposed to the effects of traumatic societal experiences have influenced the development of hybrid value systems. Thus, both in terms of domestic and in foreign policy, young people are placed in a position to make an unfair choice between desired and achievable values.

\section{BIBLIOGRAPHY}

Ilišin, V., Bouillet, D., Gvozdanović, A., \& Potočnik, D. (2013). Mladi u vremenu krize. Zagreb: Institut za društvena iztrazivanja u Zagrebu i Friedrich-Ebert-Stiftung, Zagreb.

Kuljić, T. (2009). Sociologija generacije. Beograd: Čigoja štampa.

Merton, R. K. (1968). Social Theory and Social Structure. New York: The Free Press.

Petkovska, A., Minoski, K., Popovski, M., \& Jovanoski, A. (2012). Some Aspects of the Trust among Macedonian Citizens Related to Security and Safety Issues. International Scientific Conference Security and EuroAtlantics Perspectives of the Balkans Vol. I (стр. 466-474). Skopje: St Clement of Ohrid University - Bitola, Faculty of Security - Skopje.

Schizerrotto, A., \& Gasperini, G. (eds.). (2001). Study on the State of Young People and Practice in Europe. Milano: IARD.

Агенција за млади и спорт. (2004). Основна студија за младински трендови. Скопје: Агенција за млади и спорт.

Петковска, А., Поповски, М., \& Јованоски, А. (2010). Сондирање европски вредности во Република Македонија. Социолошка ревија, 225-259. 